\title{
THE RELATIONSHIP BETWEEN AIR AND SOIL TEMPERATURE AS A LOCAL INDICATOR OF CLIMATE CHANGE IN A SMALL AGRICULTURAL CATCHMENT
}

\author{
Agnieszka J. Hejduk¹, Leszek Hejduk², Kaludia Jóźwik² \\ ${ }^{1}$ Water Center Laboratory, Warsaw University of Life Sciences-SGGW, Nowoursynowska 166, 02-787 Warsaw \\ ${ }^{2}$ Faculty of Civil and Envirnonmental Engineering, Warsaw University of Life Sciences-SGGW, Nowoursynowska 159, \\ 02-787 Warsaw
}

\begin{abstract}
Aim of the study

The aim of the study was to identify the trends in changes in air and soil temperature and their relationship, as well as to investigate if short data set can be an indicator of local climate change.
\end{abstract}

\begin{abstract}
Material and methods
The study was based on the data of air and soil temperature collected between 2009 and 2015 at Czarna gauging station. It includes calculation of the average daily, monthly, semi-annual and annual air and soil temperature at particular depths of the soil profile. Monthly average values were used to determine the relationship between air and soil temperature. Based on the maximum air temperature, the number of frost, cold, cool, warm, hot and very hot days was calculated, according to the methodology provided by the Polish Climate Atlas. The basic statistical measures, trends in temperature change and linear regression were determined, as well as the statistical significance of equation coefficients using the Student's t-test.
\end{abstract}

\section{Results and conclusions}

The study shows a statistically significant increasing trend in average air temperature in summer. The annual average and winter average air temperature demonstrate an statistically insignificant increasing trend. The number of frost days shows a decreasing trend, contrary to the number of cold and very hot days. The average soil temperature appears to be increasing for the surface layer. The monthly distribution of average soil temperature corresponds with the monthly distribution of average air temperature. There is a strong relationship between air temperature and soil temperature.

Keywords: small catchment, air temperature, soil temperature, trends in air and soil temperature

\section{INTRODUCTION}

Recently, climate changes have not only affected air temperature, but also other factors such as soil temperature and precipitation (Barman et al., 2017). Air temperature is one of the most important climatic fac- tors affecting soil temperature. In the winter season, depending on the intensity of snowfall and its fluctuations as well as the duration of snow cover, which acts as an isolator between air and soil, the reaction of soil temperature to climate change can differ significantly from the reaction of air temperature (Jungqvist

凶e-mail: agnieszka_hejduk@sggw.pl 
et al., 2014). Soil temperature is connected to many processes such as dissolution of organic substances, soil mineralization or degradation, nutrient assimilation by plants, as well as forest productivity and the length of the vegetative season (Jungqvist et al., 2014). Changes in soil temperature are most distinct up to a depth of about $20 \mathrm{~cm}$, while their amplitude decreases as the depth increases (Bryś, 2008; Szyga-Pluta, 2018). Soil temperature is shaped by factors such as: vegetation cover, periodic snow cover (Biernacka, 2010), soil water content and physiographic conditions (Kruk et al., 2018). However, according to Wojtkowski and Skowery (2017), radiation balance is the main factor of thermal conditions. Soil without cover shows much higher temperature amplitudes (Mularz and Wróbel, 2003). When air temperature drops and there is minimum insolation (i.e. at night), the temperature of soil without cover falls faster than that of soil covered by vegetation. In the evening, the temperature of soil covered with vegetation is also lower the air temperature, but higher by few degrees during the day.

In the first decade of the 21st century, an increase in air temperature was observed in spring and summer (Żmudzka, 2010; Michalska, 2009). Climate warming in Europe is also the cause of rising winter temperatures (Lorenc, 2000; Trepińska, 2001; Michalska 2011), which consequently affect the formation, duration and thickness of snow cover. Soil thermal and moisture conditions directly translate into plant growth and development, and have an impact on the length of growing season. In the years 2001-2009, the growing season in Poland was 8 days longer compared to 1971-2000, thus at the current rate of climate change by 2030 it may extend up to 14 days (Nieróbca et al., 2013). Long-term changes in the course of air and soil temperature by changing the duration of growing season may in the future affect the structure of crops and, as a result, the land use.

The main purpose of this analysis was to identify trends in air temperature and soil temperature and their interrelationships, as well as to examine whether short series of measurement data can serve as an indicator of local climate change. The study used measurement data from a hydro-metrological station located in the village of Czarna, belonging to the Faculty of Civil and Environmental Engineering, Department of Water Engineering and Applied Geology, SGGW. This station has been used since the 1960 s to monitor hydrological and metrological changes.

\section{RESEARCH AREA}

The catchment area at Czarna station $\left(51^{\circ} 25^{\prime} 37\right.$ "N $21^{\circ} 26^{\prime} 27^{\prime}$ "E) is $23.4 \mathrm{~km}^{2}$. The location of the research catchment is presented in Fig. 1. Hydrological tests covered the upper part of the catchment area that is situated in the Radom Plain. In the catchment, a monitoring system has been installed in two measuring stations: Płachty Stare and Czarna. It is a flat, locally undulating land. The average precipitation in the catchment area in the years 1963-2011 amounted to $612 \mathrm{~mm}$ and the outflow was $107 \mathrm{~mm}$ (Banasik et al., 2013). The lowest annual precipitation was reported in $1991(414 \mathrm{~mm})$, while the lowest annual outflow was recorded in $1992(52 \mathrm{~mm})$. The most important watercourses have an average slope ranging from $2.5 \%$ to $3.5 \%$, with shallow and narrow valleys (Byczkowski et al., 2001; Hejduk et al., 2015). The catchment area of the Zagożdżonka river is mainly used for agriculture. The land use till Czarna ganging station $70 \%$ of the area is arable land, $20 \%$ forests, $9.4 \%$ pasture and $0.6 \%$ hardened areas (Hejduk and Hejduk, 2014). Grasslands dominate in the watercourse valleys. Grains (rye, oats and triticale), potatoes and papilionaceous plants were grown in this area (Banasik, 1994).

The monitoring system in the Zagożdżonka catchment consists of sensors installed in the measurement section of the river and in the weather station (Hejduk et al., 2010; Banasik and Hejduk, 2013). Along with the beginning of research on winter floods (snowmelt and snowmelt-rainfall), four ground thermometers were installed in the weather station at depths of $0 \mathrm{~cm}$, $5 \mathrm{~cm}, 10 \mathrm{~cm}$ and $20 \mathrm{~cm}$ deep in the soil profile. All thermometers are placed in sandy soil and in the aeration zone. 


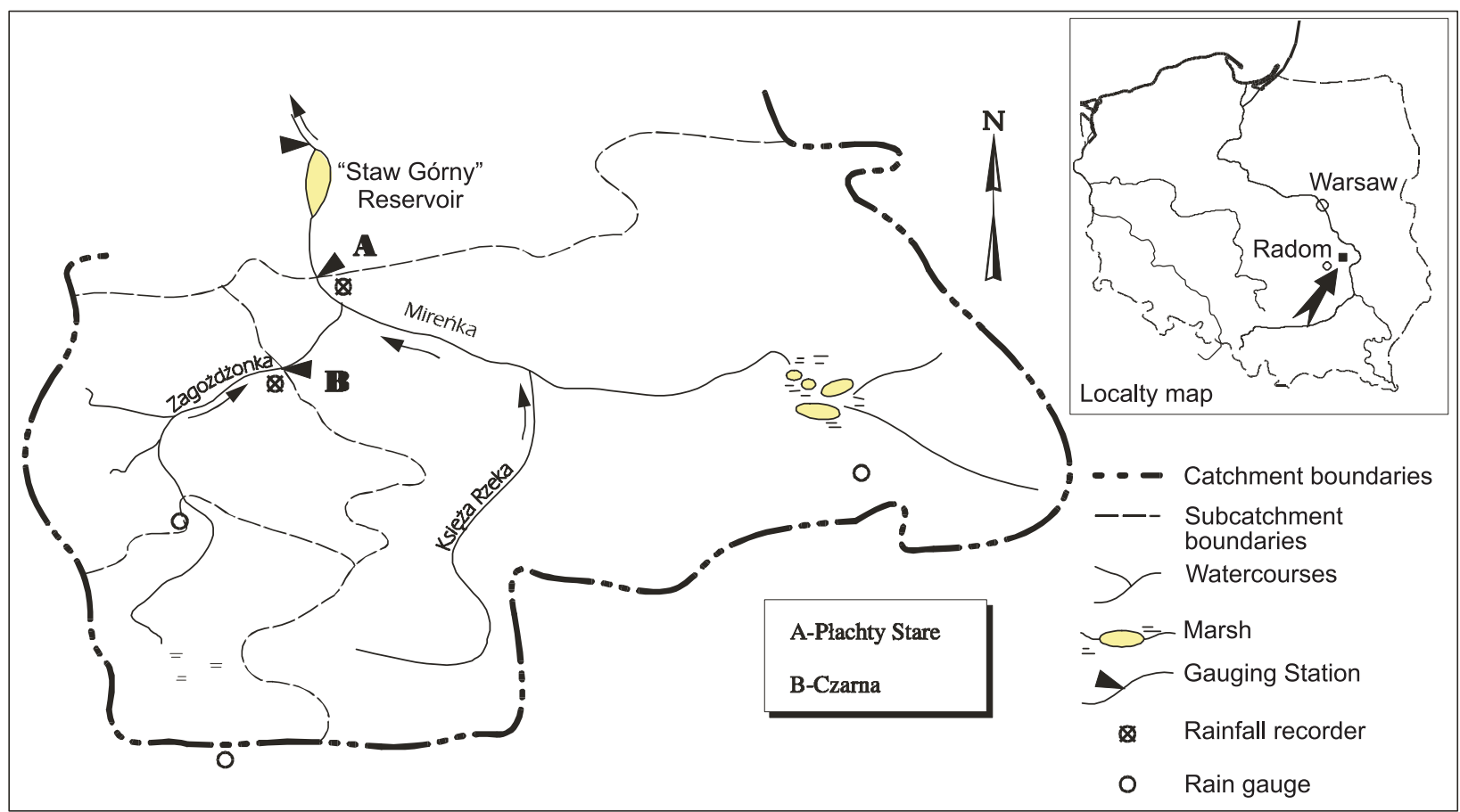

Fig. 1. Location of the research area

\section{MATERIALS AND METHODS}

Measurements of air and soil temperature, collected in the years 2009-2015 at the station in Czarna are the basis for the following calculations. The measurement of both air and soil temperature was taken automatically with a ten-minute time step. Occurring deficiencies in data were supplemented on the basis of equations determining the relationship between the temperature value at the measuring station in Czarna and the nearby weather station IMGW in Kozienice (Jóźwik, 2019). Using the available data, the minimum, maximum and average daily air and soil temperature were calculated at individual depths of the soil profile. On this basis, the monthly average, semi-annual average (separately for winter and summer half-years) and annual temperature were determined. Monthly average values also allowed determining the relationship between air and soil temperature at individual depths.

In order to characterize the thermal conditions in the studied area, the number of frosty, cold, cool, warm, hot and very hot days was calculated on the basis of the maximum air temperature, in accordance with the methodology given in the Polish Climate Atlas (Lorenz, 2005). If the maximum temperature $\left(t_{\max }\right)$ does not exceed $0^{\circ} \mathrm{C}$ during the day, we consider it a frost day; when temperature $t_{\max } \leq 10^{\circ} \mathrm{C}-$ it is a cold day; when $t_{\text {max }}$ is in the range from $10.1^{\circ} \mathrm{C}$ to $15.0^{\circ} \mathrm{C}$, we consider the day to be cool; $t_{\max }$ in the range between $18.1^{\circ} \mathrm{C}$ and $23.0^{\circ} \mathrm{C}$ defines a warm day; $t_{\max }$ taking values from $25.1^{\circ} \mathrm{C}$ to $30.0^{\circ} \mathrm{C}$ indicates a hot day, and when the maximum temperature exceeds $30.0^{\circ} \mathrm{C}$ a day is considered very hot.

The trends of temperature changes as well as linear regression (the relationship between soil temperature at different depths and air temperature) were determined on the measured data. The statistical significance of equation coefficients was checked for both trends and linear regression equations using the t-Student's test. Basic statistical measures, i.e. mean values (mean), standard deviation (SD), coefficient of variation (ratio of standard deviation to mean value $-V_{t}$ ), range i.e. the difference between the maximum and minimum val- 
ues $\left(R_{o}\right)$ and the medium-term rate of change (geometric mean of individual chain indexes $-T$ ) expressed in percentages (Pralińska, Praliński 2003).

\section{RESULTS}

\section{Air temperature variation}

The average air temperature for the period 2009-2015 at the station in Czarna was $8.6^{\circ} \mathrm{C}$, ranging from $7.7^{\circ} \mathrm{C}$ in 2013 to $9.4^{\circ} \mathrm{C}$ in 2014 and 2015 . The average monthly temperature ranged from $-2.3^{\circ} \mathrm{C}$ in January to $19.5^{\circ} \mathrm{C}$ in July. The variation of the average annual air temperature and the average temperature of the winter and summer half-years is shown in Fig. 2

The trend line equations of changes in the average annual air temperature and the average air temperature of the winter and the summer half-years along with selected measures of variation are presented in Tab. 1. Both in annual and semi-annual terms, the average air temperature is showing a rising trend. It is respectively $0.19^{\circ} \mathrm{C}$ per year, $0.14^{\circ} \mathrm{C}$ in the summer half-year and $0.23^{\circ} \mathrm{C}$ in the winter half-year. However, only in the summer half-year the trend line equation coefficients were statistically significant at the level $p=0.1$. The standard deviation, temperature coefficient of variation and range were much larger in the winter halfyear. This indicates that air temperature in the winter period is characterized by much greater variation and diversity than in the summer period. This is also evidenced by the medium-term rate of change, demonstrating the percentage increase in temperature from year to year, which was the largest for the winter halfyear and amounted to $6.59 \%$.

Given the average monthly temperature, the coldest months were respectively January, February and December (see: Fig. 3). Positive average temperature values were recorded in November, March and April. March is characterized by variable weather, snowfall, negative and positive air temperatures may occur. Similarly, November can be warm, with typical autumn

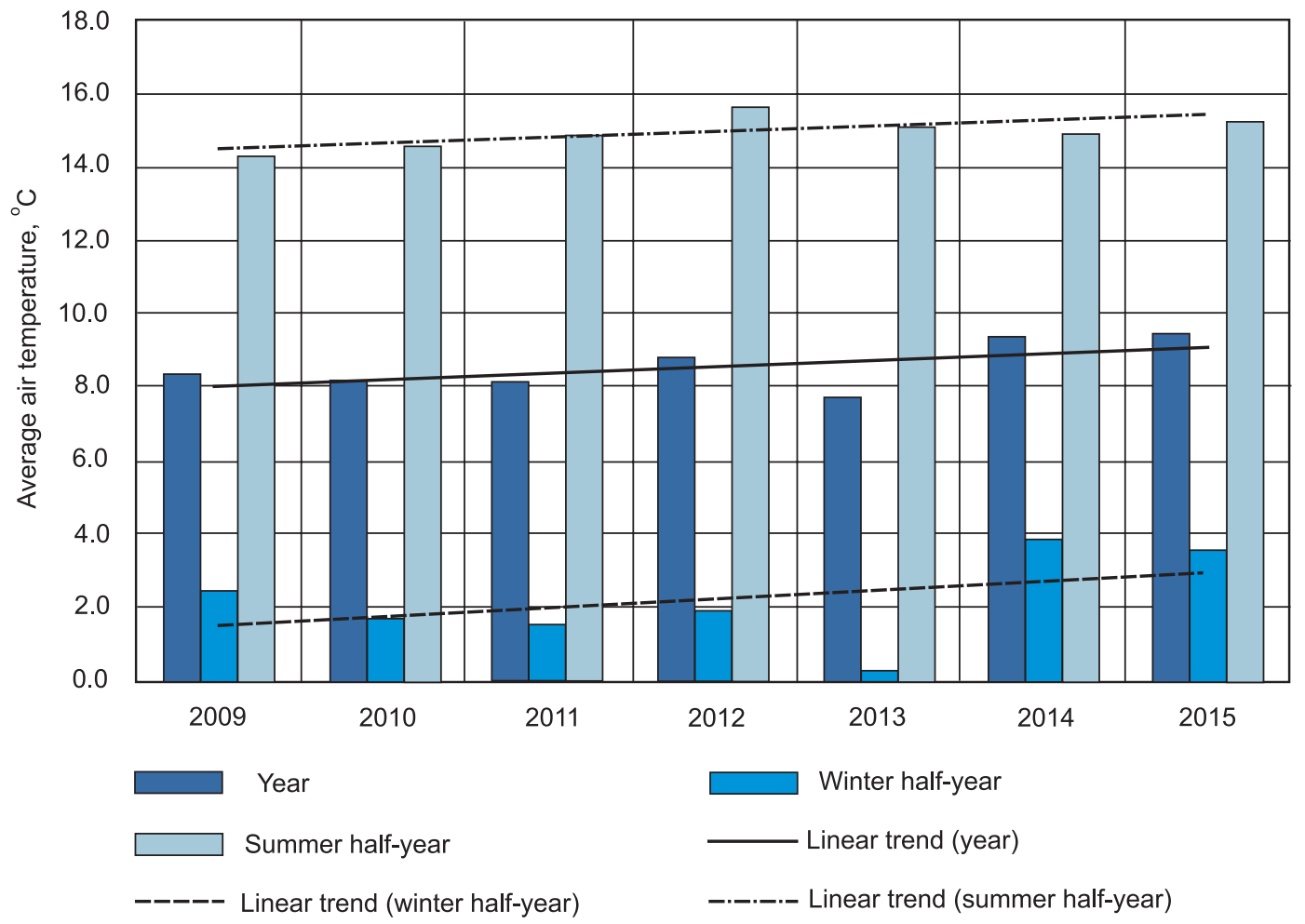

Fig. 2. Average air temperature for individual years and both the summer and the winter half-years of the period 2009-2015 in Czarna 
Table 1. Summary of trend line equations and selected variation characteristics for the average temperature on an annual and semi-annual basis

\begin{tabular}{lcccccccccc}
\hline Period & Equation & $\mathrm{R}^{2}$ & $\begin{array}{c}\text { Average } \\
\left({ }^{\circ} \mathrm{C}\right)\end{array}$ & $\begin{array}{c}\mathrm{SD} \\
\left({ }^{\circ} \mathrm{C}\right)\end{array}$ & $\begin{array}{c}\mathrm{V}_{\mathrm{t}} \\
(\%)\end{array}$ & $\begin{array}{c}\mathrm{R}_{\mathrm{O}} \\
\left({ }^{\circ} \mathrm{C}\right)\end{array}$ & $\begin{array}{c}\mathrm{T} \\
(\%)\end{array}$ & Statistics t & $\begin{array}{c}\text { Significance } \\
\text { at } \mathrm{p}\end{array}$ \\
\hline summer half-year & $\mathrm{Y}=0.143 \cdot \mathrm{X}-274.08$ & 0,44 & 14,9 & 0,47 & 3 & 1,4 & 1,13 & 1,975 & 0,105 \\
\hline winter half-year & $\mathrm{Y}=0.232 \cdot \mathrm{X}-465.57$ & 0,16 & 2,2 & 1,4 & 57 & 3,6 & 6,59 & 0,993 & 0,366 \\
\hline year & $\mathrm{Y}=0.188 \cdot \mathrm{X}-369.82$ & 0,39 & 8,6 & 0,65 & 8 & 1,7 & 2,02 & 1,782 & 0,134 \\
\hline
\end{tabular}

given that $\mathrm{Y}$ - average air temperature, $\mathrm{X}$ - years

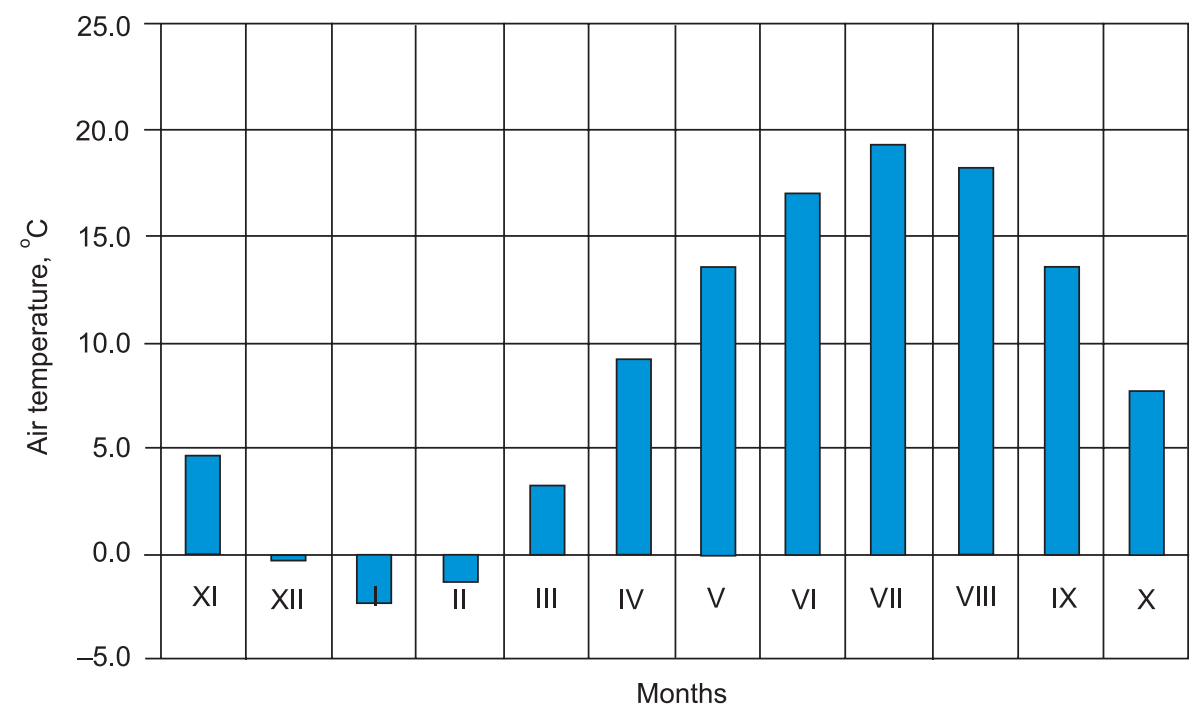

Fig. 3. Monthly distribution of average air temperature over the years 2009-2015 at the measurement station in Czarna

weather, or cool. At the station in Czarna, the first snow cover often appears at the end of November, but the average temperature of this month is positive (Hejduk and Hejduk, 2014). In the studied period, the warmest months were July, August and June, respectively. The average temperature in May and September was similar.

Analysing the variation of air temperature for individual months (see: Table 2), defined as the difference between the maximum and minimum average temperature of a given month, the highest dynamics were recorded in the winter months, i.e. January and March. The average January temperature ranged from $-8.1^{\circ} \mathrm{C}$ in 2010 to $2.3^{\circ} \mathrm{C}$ in 2015 . In March, the lowest average temperature $\left(-1.9^{\circ} \mathrm{C}\right)$ was registered in 2013 , and the highest a year later $\left(6.0^{\circ} \mathrm{C}\right)$. The smallest variation of the average monthly air temperature in the studied pe- riod was noted in April (from $8.1^{\circ} \mathrm{C}$ in 2015 to $10.1^{\circ} \mathrm{C}$ in 2011). In the remaining months, the difference between the lowest and the highest average monthly air temperature was $4.5^{\circ} \mathrm{C}$ on average. In seasonal terms, smaller temperature differences were recorded for the summer half-year (average $3.4^{\circ} \mathrm{C}$ ).

Based on the maximum daily air temperature, the number of frost, cold, cool, warm, hot and very hot days (see: Fig. 4) was calculated. Trend line equations for the analysed days are summarized in Tab. 3, and their statistical characteristics are presented in Tab. 4. In the examined period, a total of 212 frost days were recorded, in which the maximum temperature did not exceed $0^{\circ} \mathrm{C}$. The least frost days occurred in 2014-2015. In 2014, there were 16, and in 2015 only 15. Analysis of individual types of days in the analysed 
Hejduk,A.J., Hejduk, L., Jóźwik, K. (2019). The relationship between air and soil temperature as a local indicator of climate change in a small agricultural catchment. Acta Sci. Pol., Formatio Circumiectus, 18 (4), 161-175. DOI: http://dx.doi.org/10.15576/ASP.FC/2019.18.4.161

Table 2. The range of average monthly air temperature in the years 2009-2015 at the measurement station in Czarna

\begin{tabular}{lccc}
\hline \multicolumn{1}{c}{ Month } & Range & $\begin{array}{c}\text { The warmest } \\
\text { in year }\end{array}$ & $\begin{array}{c}\text { The coldest } \\
\text { in year }\end{array}$ \\
\hline November & $2.3-6.2^{\circ} \mathrm{C}$ & 2011 & 2012 \\
\hline December & $-5,5-2,4^{\circ} \mathrm{C}$ & 2012 & 2011 \\
\hline January & $-8,1^{\circ} \mathrm{C}-2,3^{\circ} \mathrm{C}$ & 2015 & 2010 \\
\hline February & $-6,2^{\circ} \mathrm{C}-1,9^{\circ} \mathrm{C}$ & 2014 & 2012 \\
\hline March & $-1.9^{\circ} \mathrm{C}-6.0^{\circ} \mathrm{C}$ & 2014 & 2013 \\
\hline April & $-8,1^{\circ} \mathrm{C}-10,1^{\circ} \mathrm{C}$ & 2011 & 2015 \\
\hline May & $12,7^{\circ} \mathrm{C}-15,0^{\circ} \mathrm{C}$ & 2012 & 2009,2015 \\
\hline June & $15,5^{\circ} \mathrm{C}-18,2^{\circ} \mathrm{C}$ & 2011 & 2014 \\
\hline July & $17,5^{\circ} \mathrm{C}-21,2^{\circ} \mathrm{C}$ & 2010 & 2011 \\
\hline August & $17,3^{\circ} \mathrm{C}-21,3^{\circ} \mathrm{C}$ & 2015 & 2009 \\
\hline September & $11,3^{\circ} \mathrm{C}-14,8^{\circ} \mathrm{C}$ & 2015 & 2013 \\
\hline October & $-1.9^{\circ} \mathrm{C}-6.0^{\circ} \mathrm{C}$ & 2013 & 2010 \\
\hline
\end{tabular}

period indicates a downward trend for frost days (see: Fig. 4). On a monthly basis, the largest number of frost days was recorded for January (95 days in total), February (55 days) and December (43 days).

In the summer period, in the years 2009-2015, 77 very hot days were registered with a maximum temperature exceeding $30^{\circ} \mathrm{C}$, with the most, as many as 22 days, in 2015. The frequency of very hot days in the studied period shows an upward trend. A total of 81 hot days were recorded, with a maximum temperature ranging from $25.1^{\circ} \mathrm{C}$ to $30.0^{\circ} \mathrm{C}$. In the years 2009 -2015 hot days were typical for July. On a monthly basis, the most very hot days $\left(t_{\max }>30^{\circ} \mathrm{C}\right)$ in the studied period were registered in August, (34 days) and in July (33 days), and occasionally appeared in June (5 days) and in September (3 days). On average, there were 30 frost days, 112 cold days, 52 cool days, 67 warm days, 38 hot days and 11 very hot days.

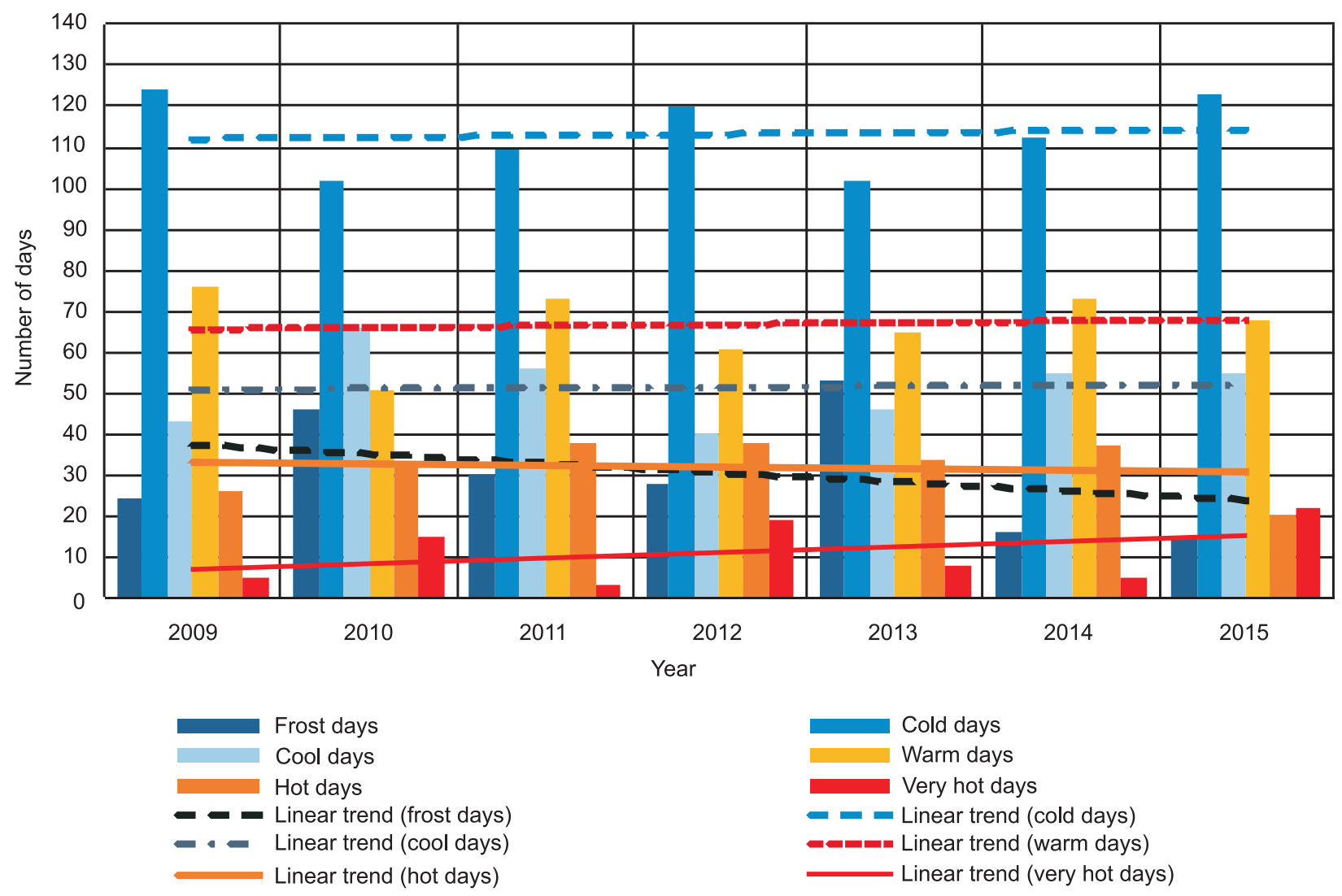

Fig. 4. Number of frost, cold, cool, warm, hot and very hot days occurring in the years 2009-2015 at the station in Czarna 
Hejduk,AJ., Hejduk, L., Jóźwik, K.(2019). The relationship between air and soil temperature as a local indicator of climate change in a small agricultural catchment. Acta Sci. Pol., Formatio Circumiectus, 18 (4), 161-175. DOI: http://dx.doi.org/10.15576/ASP.FC/2019.18.4.161

Table 3. Trend line equations for calculated frost, cold, cool, warm, hot and very hot days.

\begin{tabular}{lcccc}
\hline \multicolumn{1}{c}{ Trend for: } & Equation & $\mathrm{R}^{2}$ & Statistics $\mathrm{t}$ & Significance at $\mathrm{p}$ \\
\hline number of frost days & $\mathrm{Y}=-2.285 \cdot \mathrm{X}+4629.14$ & 0,12 & 0,815 & 0,451 \\
\hline number of cold days & $\mathrm{Y}=0.392 \cdot \mathrm{X}-677.00$ & 0,008 & 0,204 & 0,845 \\
\hline number of cool days & $\mathrm{Y}=0.143 \cdot \mathrm{X}-274.08$ & 0,001 & 0,076 & 0,942 \\
\hline number of warm days & $\mathrm{Y}=0.428 \cdot \mathrm{X}-795.57$ & 0,01 & 0,240 & 0,819 \\
\hline number of hot days & $\mathrm{Y}=0.428 \cdot \mathrm{X}-894.42$ & 0,02 & 0,305 & 0,772 \\
\hline number of very hot days & $\mathrm{Y}=1.29 \cdot \mathrm{X}-2575.86$ & 0,13 & 0,878 & 0,419 \\
\hline
\end{tabular}

given that $\mathrm{Y}$ - number of days, $\mathrm{X}$ - year

Table 4. Comparing the selected coefficients of variation for calculated very hot, hot, warm, cool, cold and frost days.

\begin{tabular}{cccccccc}
\hline \multirow{2}{*}{ Parameter } & \multirow{2}{*}{ Unit } & \multicolumn{7}{c}{ Days } \\
\cline { 3 - 9 } & & Very hot & Hot & Warm & Cool & Cold & Frost \\
\hline Average & (days) & 11,0 & 32,1 & 66,7 & 51,6 & 113,4 & 30,3 \\
\hline $\mathrm{SD}$ & (days) & 7,59 & 6,84 & 8,65 & 9,03 & 9,31 & 14,41 \\
\hline $\mathrm{V}_{\mathrm{t}}$ & $(\%)$ & 69 & 21 & 13 & 18 & 8 & 48 \\
\hline $\mathrm{R}_{\mathrm{o}}$ & $($ days $)$ & 19 & 18 & 25 & 26 & 22 & 38 \\
\hline $\mathrm{T}$ & $(\%)$ & 28,01 & $-4,28$ & $-1,84$ & 4,19 & $-0,13$ & $-7,53$ \\
\hline
\end{tabular}

The number of frost and hot days (see: Fig. 4) showed values decreasing by 2 and 3 days per year respectively, however, statistical analysis (see: Table 3) showed no significance of regression. In other cases, i.e. for the number of cool, cold, warm and very hot days, an upward trend was proven. For very hot days it was 1.3 days a year, while in other cases from 0.14 through 0.39 to 0.43 days a year. In all cases, statistical analysis (see: Table 3) showed no significance of regression.

The standard deviation (see: Table 4) was greatest for the number of frost days (14.41) and similar for cool and cold days (9 and 9.3). The smallest recorded value of the standard deviation was for the number of hot days. The largest variation coefficients were recorded for the number of very hot days $(69 \%)$ and frost days $(48 \%)$, with the largest range measured for the number of frost days (38). The medium-term rate of change was positive only for the number of very hot and cool days. In other cases, the values of this indicator were negative. This means that the number of days increased from year to year only for very hot and cool days.

\section{Soil temperature variation}

For the examined period and individual depths of the soil profile, the average, minimum and maximum soil temperature was calculated on an annual, semi-annual and monthly basis (see: Fig. 5). The average soil temperature at a depth of $0 \mathrm{~cm}$ (i.e. right next to the ground) in the years $2009-2015$ was $10.8^{\circ} \mathrm{C}$. It fluctuated from $10.1^{\circ} \mathrm{C}$ in 2013 to $11.3^{\circ} \mathrm{C}$ in 2014 . In seasonal terms, the average soil temperature at a depth of $0 \mathrm{~cm}$ in the winter half-year was $4.6^{\circ} \mathrm{C}$. Its lowest value was recorded in $2013\left(3.4^{\circ} \mathrm{C}\right)$ and the highest in $2014\left(5.7^{\circ} \mathrm{C}\right)$. The average soil temperature at a depth of $0 \mathrm{~cm}$ in the summer half-year was $17.0^{\circ} \mathrm{C}$ and ranged from $16.7^{\circ} \mathrm{C}$ in 2009 to $17.6^{\circ} \mathrm{C}$ in 2012 . The average soil temperature at a depth of $5 \mathrm{~cm}$ was $10.9^{\circ} \mathrm{C}$. Its lowest value was registered in $2013\left(10.2^{\circ} \mathrm{C}\right)$ and the highest $\left(11.2^{\circ} \mathrm{C}\right)$ in 


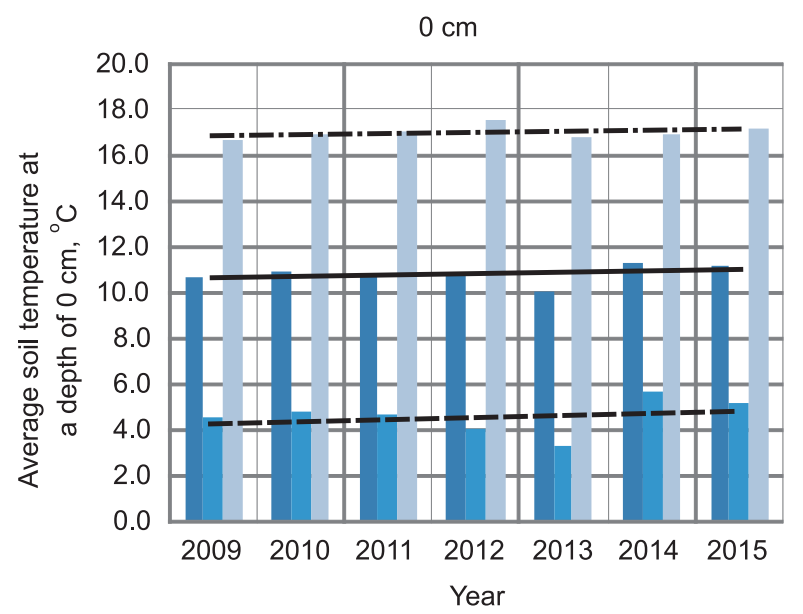

$10 \mathrm{~cm}$

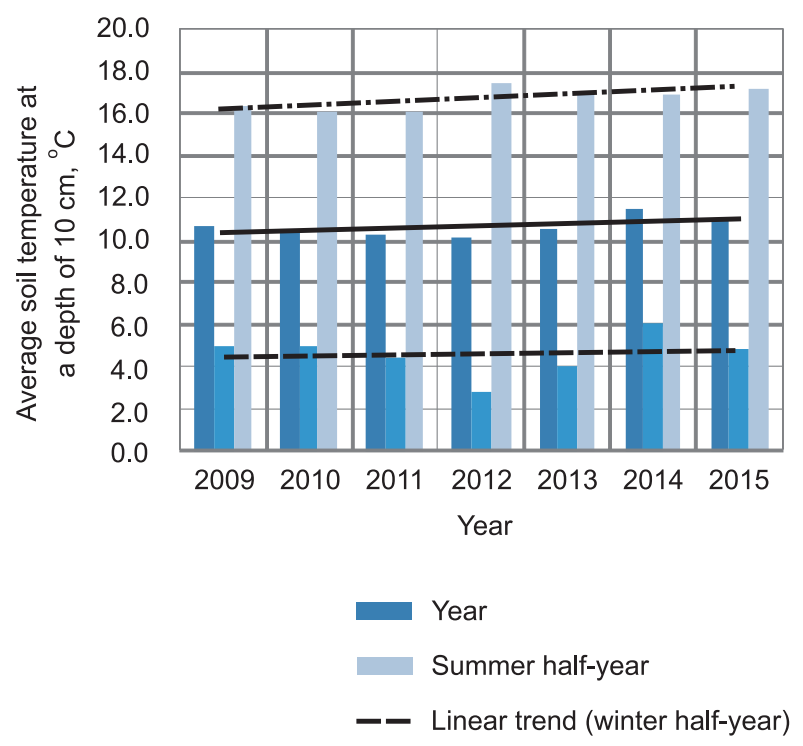

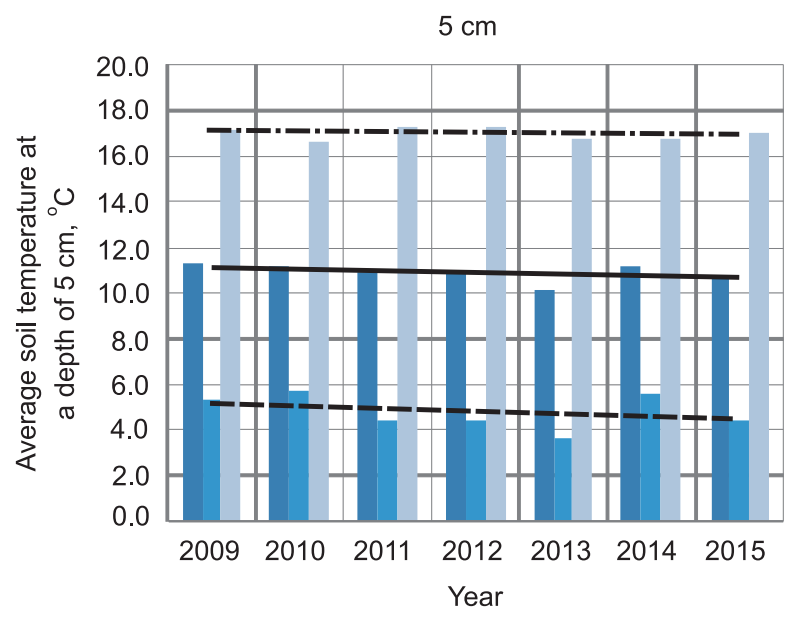

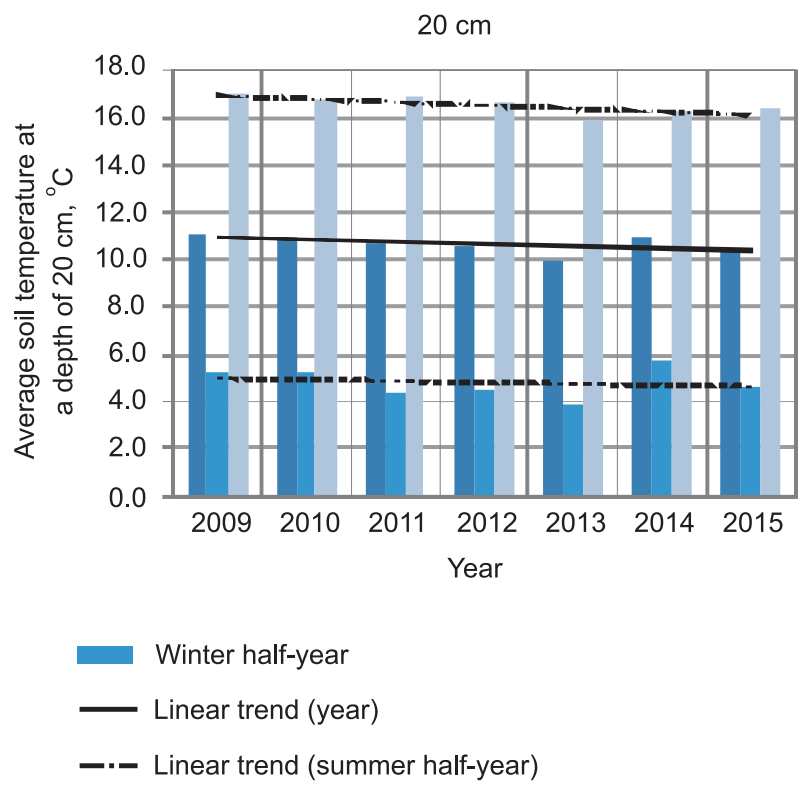

Fig. 5. Average soil temperature at a depth of $0 \mathrm{~cm}, 5 \mathrm{~cm}, 10 \mathrm{~cm}, 20 \mathrm{~cm}$ for individual years and the summer and winter half-years of the 2009-2015 period

2009 and 2010. On a seasonal basis, the average soil temperature at a depth of $5 \mathrm{~cm}$ in the winter for the 2009-2015 period was $4.8^{\circ} \mathrm{C}$, varying between $3.6^{\circ} \mathrm{C}$ in 2013 and $5.7^{\circ} \mathrm{C}$ in 2010 . In the summer half-year it was $17.0^{\circ} \mathrm{C}$ and oscillated between $16.7^{\circ} \mathrm{C}$ in 2010 and 2014 to $17.4^{\circ} \mathrm{C}$ in 2012 . The average soil temperature at a depth of $10 \mathrm{~cm}$ in the 2009-2015 period at the station in Czarna was $10.7^{\circ} \mathrm{C}$. The coldest year turned out to be $2012\left(10.1^{\circ} \mathrm{C}\right)$, while the warmest was 2014 with an average of $11.5^{\circ} \mathrm{C}$. In seasonal terms, the average soil temperature at a depth of $10 \mathrm{~cm}$ in the winter half-year was $4.6^{\circ} \mathrm{C}$ and ranged from $2.8^{\circ} \mathrm{C}(2012)$ to $6.1^{\circ} \mathrm{C}$ (2014). In summer, the average temperature at the level of $10 \mathrm{~cm}$ was $16.8^{\circ} \mathrm{C}$. The coolest summer half-year was recorded in 2010 and $2011\left(16.2^{\circ} \mathrm{C}\right)$, and the warmest in 2012 $\left(17.5^{\circ} \mathrm{C}\right)$. The average soil temperature at a depth of $20 \mathrm{~cm}$ in the $2009-2015$ period was $10.7^{\circ} \mathrm{C}$. The coldest year was $2013\left(9.9^{\circ} \mathrm{C}\right)$, the warmest $-2009\left(11.1^{\circ} \mathrm{C}\right)$. The average soil temperature at a depth of $20 \mathrm{~cm}$ for the winter half-year was $4.8^{\circ} \mathrm{C}$, varying between $3.9^{\circ} \mathrm{C}$ in 2013 and $5.8^{\circ} \mathrm{C}$ in 2014 . In the summer period, the average soil temperature at a depth of $20 \mathrm{~cm}$ was $16.6^{\circ} \mathrm{C}$. 
Table 5. Trend line equations for the average temperature at individual depths of the soil profile

\begin{tabular}{|c|c|c|c|}
\hline \multirow{2}{*}{ Soil profile depth } & \multicolumn{3}{|c|}{ Trend line equation } \\
\hline & Year & Summer half-year & Winter half-year \\
\hline $0 \mathrm{~cm}$ & $Y_{0}=0.065 \cdot X_{0}-120.66$ & $Y_{0}=0.041 \cdot X_{0}-65.35$ & $Y_{0}=0.089 \cdot X_{0}-175.97$ \\
\hline $5 \mathrm{~cm}$ & $Y_{5}=-0.077 \cdot X_{5}+167.09$ & $Y_{5}=-0.027 \cdot X_{5}+70.88$ & $Y_{5}=-0.128 \cdot X_{5}+263.31$ \\
\hline $10 \mathrm{~cm}$ & $Y_{10}=0.111 \cdot X_{10}-213.51$ & $\mathrm{Y}_{10}=0.168 \cdot \mathrm{X}_{10}-321.75$ & $Y_{10}=0.05 \cdot 4 X_{10}-105.28$ \\
\hline $20 \mathrm{~cm}$ & $Y_{20}=-0.095 \cdot X_{20}+202.99$ & $Y_{20}=-0,143 \cdot X_{20}+304.53$ & $Y_{20}=-0.048 \cdot X_{20}+101.46$ \\
\hline
\end{tabular}

given that $\mathrm{Y}_{\text {index }}$ - soil temperature at an individual depth, $\mathrm{X}_{\text {index }}-$ years

Table 6. Comparison of selected statistical characteristics

\begin{tabular}{cccccccccc}
\hline \multirow{2}{*}{$\begin{array}{c}\text { Soil profile } \\
\text { depth }\end{array}$} & \multicolumn{4}{c}{ Year } & \multicolumn{3}{c}{ Summer half-year } & \multicolumn{2}{c}{ Winter half-year } \\
\cline { 2 - 11 } & $\mathrm{R}^{2}$ & Statistics t & Significance at $\mathrm{p}$ & $\mathrm{R}^{2}$ & Statistics t & Significance at $\mathrm{p}$ & $\mathrm{R}^{2}$ & Statistics t & Significance at $\mathrm{p}$ \\
\hline $0 \mathrm{~cm}$ & 0.13 & 0.874 & 0.421 & 0.10 & 0.764 & 0.479 & 0.07 & 0.609 & 0.569 \\
\hline $5 \mathrm{~cm}$ & 0.20 & 1.132 & 0.308 & 0.04 & 0.472 & 0.656 & 0.13 & 0.873 & 0.422 \\
\hline $10 \mathrm{~cm}$ & 0.26 & 1.324 & 0.242 & 0.52 & 2.337 & 0.066 & 0.01 & 0.262 & 0.803 \\
\hline $20 \mathrm{~cm}$ & 0.24 & 1.257 & 0.264 & 0.64 & 2.978 & 0.031 & 0.03 & 0.364 & 0.730 \\
\hline
\end{tabular}

The coolest summer occurred in $2013\left(16.0^{\circ} \mathrm{C}\right)$, and the warmest in $2009\left(17.0^{\circ} \mathrm{C}\right)$. Trend line equations for the average temperature at individual depths of the soil profile are summarized in Tab. 5, and in Tab. 6 their selected characteristics. Table 7 presents a summary of selected coefficients of variation for the average temperature at individual depths of the soil profile.

The trend line equation coefficients presented in Tab. 5 are significant at the significance level $p=0.05$ only for the trend of soil temperature variation at a depth of $20 \mathrm{~cm}$ for the summer half-year (see: Table 6), and are significant at the significance level $\mathrm{p}=0.1$ only for the trend of soil temperature variation at a depth of $10 \mathrm{~cm}$ for the summer half-year.

The trend line equations presented in Tab. 5, selected statistical characteristics (see: Table 6) and measures of variation (see: Table 7) suggest an upward trend in average temperature at $0 \mathrm{~cm}$ and $10 \mathrm{~cm}$ depths and a downward trend at $5 \mathrm{~cm}$ and $20 \mathrm{~cm}$ depths. The directional coefficients of trend line equations for all soil profile depths were close to zero. The highest standard deviation was recorded for the average soil temperature in the winter half-year. This applied to all depths of the soil profile. The standard deviation of the average annual soil temperature and the average summer period temperature were at a similar level. The average soil temperature at all depth levels showed the highest values of the coefficient of variation in the winter period. The medium-term rate of change was positive only for the average temperature at a depth of $0 \mathrm{~cm}$ both in an annual and semi-annual scale.

The monthly distribution of average soil temperature at individual depths of the soil profile is shown in Fig. 6.

Considering the average monthly soil temperature measured at a depth of $5 \mathrm{~cm}$, the coolest month was February $\left(1.4^{\circ} \mathrm{C}\right)$, and the warmest was July $\left(20.7^{\circ} \mathrm{C}\right)$. At a depth of $10 \mathrm{~cm}$, the average soil temperature ranged from $1.6^{\circ} \mathrm{C}$ in February to $20.2^{\circ} \mathrm{C}$ in July. At a depth of $20 \mathrm{~cm}$, the lowest average temperature was also recorded in February $\left(1.7^{\circ} \mathrm{C}\right)$, the highest in July $\left(19.9^{\circ} \mathrm{C}\right)$. At all analysed depths of the soil profile, the average temperature decreased from August to February, while it increased from March to July. 
Hejduk,A.J., Hejduk, L., Jóźwik, K. (2019). The relationship between air and soil temperature as a local indicator of climate change in a small agricultural catchment. Acta Sci. Pol., Formatio Circumiectus, 18 (4), 161-175. DOI: http://dx.doi.org/10.15576/ASP.FC/2019.18.4.161

Table 7. Comparison of selected coefficients of variation for the average temperature at individual depths of the soil profile.

\begin{tabular}{|c|c|c|c|c|}
\hline & \multirow{2}{*}{ Unit } & \multicolumn{3}{|c|}{ Average temperature } \\
\hline & & Annual & Winter half-year & Summer half-year \\
\hline \multicolumn{5}{|l|}{ For 0 $(\mathrm{cm}):$} \\
\hline mean & $\left({ }^{\circ} \mathrm{C}\right)$ & 10.8 & 4.6 & 17.0 \\
\hline SD & $\left({ }^{\circ} \mathrm{C}\right)$ & 0.39 & 0.74 & 0.27 \\
\hline$V_{t}$ & $(\%)$ & 4 & 16 & 2 \\
\hline $\mathrm{R}_{\mathrm{o}}$ & $\left({ }^{\circ} \mathrm{C}\right)$ & 1.2 & 2.3 & 0.8 \\
\hline $\mathrm{T}$ & $(\%)$ & 0.84 & 2.36 & 0.41 \\
\hline \multicolumn{5}{|l|}{ For $5(\mathrm{~cm}):$} \\
\hline mean & $\left({ }^{\circ} \mathrm{C}\right)$ & 10.9 & 4.8 & 17.0 \\
\hline $\mathrm{SD}$ & $\left({ }^{\circ} \mathrm{C}\right)$ & 0.37 & 0.76 & 0.28 \\
\hline$V_{t}$ & $(\%)$ & 3 & 16 & 2 \\
\hline $\mathrm{R}_{\mathrm{o}}$ & $\left({ }^{\circ} \mathrm{C}\right)$ & 1.1 & 2.1 & 0.6 \\
\hline $\mathrm{T}$ & $(\%)$ & -0.70 & -2.89 & -0.06 \\
\hline \multicolumn{5}{|l|}{ For $10(\mathrm{~cm})$ : } \\
\hline mean & $\left({ }^{\circ} \mathrm{C}\right)$ & 10.7 & 4.6 & 16.8 \\
\hline SD & $\left({ }^{\circ} \mathrm{C}\right)$ & 0.47 & 1.01 & 0.50 \\
\hline$V_{t}$ & $(\%)$ & 4 & 22 & 3 \\
\hline $\mathrm{R}_{\mathrm{o}}$ & $\left({ }^{\circ} \mathrm{C}\right)$ & 1.4 & 3.3 & 1.3 \\
\hline $\mathrm{T}$ & $(\%)$ & 0.50 & -0.61 & 0.83 \\
\hline \multicolumn{5}{|l|}{ For $20(\mathrm{~cm}):$} \\
\hline mean & $\left({ }^{\circ} \mathrm{C}\right)$ & 10.7 & 4.80 & 16.56 \\
\hline SD & $\left({ }^{\circ} \mathrm{C}\right)$ & 0.42 & 0.65 & 0.39 \\
\hline $\mathrm{V}_{\mathrm{t}}$ & $(\%)$ & 4 & 13 & 2 \\
\hline $\mathrm{R}_{\mathrm{o}}$ & $\left({ }^{\circ} \mathrm{C}\right)$ & 1.19 & 1.87 & 1.07 \\
\hline $\mathrm{T}$ & $(\%)$ & -0.98 & -2.15 & -0.64 \\
\hline
\end{tabular}

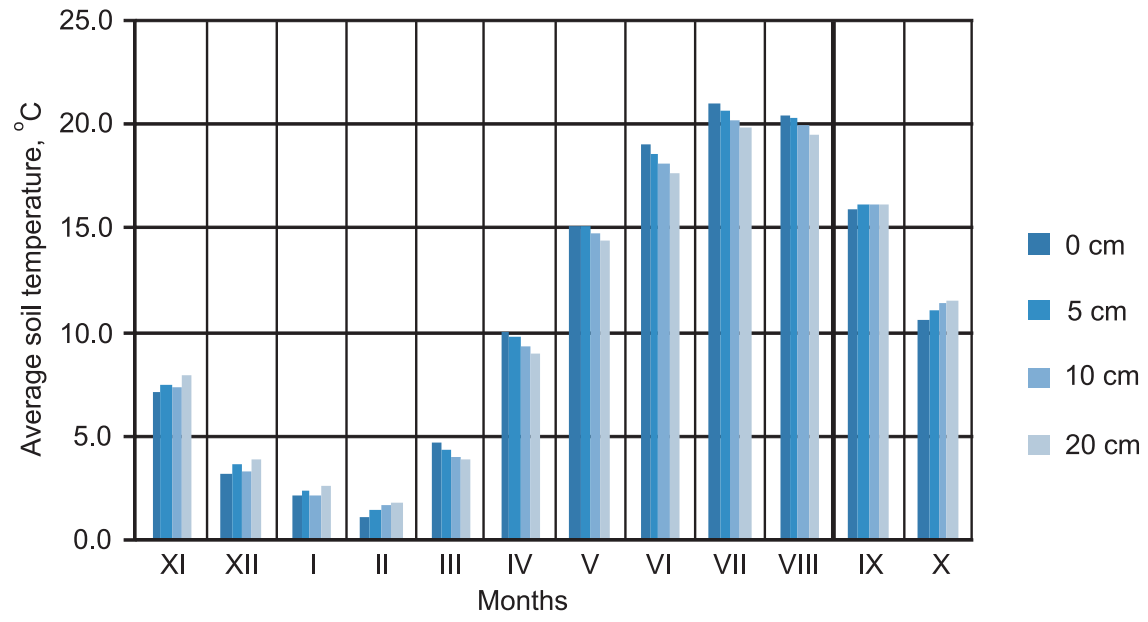

Fig. 6. Monthly distribution of average soil temperature at individual depths of the soil profile in 2009-2015 at the station in Czarna 


\section{Relationship between average monthly soil temperature and average monthly air temperature} The relationship between the average monthly soil temperature and the average monthly air temperature was determined using linear regression equations. Equations and correlation coefficients are summarized in Tab. 8. At all analysed depths of the soil profile, a strong relationship between soil temperature and air temperature was indicated. The correlation coefficient (R) was above 0.96 in all cases, and the directional coefficients of the equations were close to 1 . The strongest relationship occurs in the relationship between soil temperature and air temperature at the ground surface. Both linear regression equation coefficients and correlation coefficients are statistically significant at a significance level of $\mathrm{p}=0.05$.

\section{RESULTS DISCUSSION}

The presented analysis of variation of annual and seasonal average air and soil temperature at the station in Czarna covers a relatively short period (2009-2015). However, the obtained results, responding to climate change, are consistent with global and national reports on changes in trends in the average air temperature. A statistically significant trend of increasing average air temperature in the summer half-year was demonstrated for the station in Czarna. The trend in average air temperature in winter and annually is analogous, i.e. it also shows an upward trend, but in both cases it is not statistically significant.

Climate change is manifested in, among others, increase in average air temperature on a global and local scale. Temperature trends in the subsequent decades of the period 1951-2005 in Poland indicate a systematic increase since the 1980 s, and this trend is particularly intensified in the early spring and spring (Michalska, 2011). The average air temperature in Poland increases by about $0.2^{\circ} \mathrm{C}$ per decade (Marosz et al., 2011; Michalska, 2011). At the beginning of the 21 st century, extremely warm months were recorded in winter in Poland, mostly in November and April (Polish Climate Monitoring Bulletin, 2015). The warmest winter was recorded in 2015. The months from November 2014 to April 2015 were between slightly warm and abnormally warm. The thermal classification of year periods for reference meteorological stations (standard period 1971-2000, according to the H. Lorenc classification) clearly shows that after 2000 warm and even abnormally warm summers appear more often, while the years 2014 and 2015 were classified at some stations as extremely warm (PSHM Bulletin, 2015). In light of the report of the World Meteorological Organization (WMO), 2018 was recognized as the fourth warmest year in history (WMO, 2018). The average global temperature in the first ten months of 2018 exceeded by $0.98^{\circ} \mathrm{C}$ the level from $1850-1900$. The years of 2015-2018 period is regarded as the four warmest in measurements history.

Undoubtedly, air temperature is a factor determining the formation and retention of snow cover. Czarnecka (2012) studying the temporal and spatial variation of snow cover in Poland from November to March in the winter seasons 1960/61-2009/10 of 40 IMGW meteorological stations, found that the incidence and thickness of snow cover showed a downward trend, with no statistical significance for most stations. A statistically significant downward trend in the number of days with snow cover was recorded in December and January. Czarnecka also states that in the second half of

Table 8. The relationship between the average monthly air temperature and the average monthly soil temperature at individual depths of the soil profile

\begin{tabular}{ccccc}
\hline $\begin{array}{c}\text { Temperature at } \\
\text { depth: }\end{array}$ & Equation & $\begin{array}{c}\text { Correlation } \\
\text { coefficient }(\mathrm{R})\end{array}$ & $\begin{array}{c}\text { Statistics } \\
\mathrm{t}\end{array}$ & \multicolumn{2}{c}{$\begin{array}{c}\text { Significance } \\
\text { at } \mathrm{p}\end{array}$} \\
\hline $0 \mathrm{~cm}$ & $\mathrm{Y}=0.9058 \cdot \mathrm{X}+3.0171$ & $\mathrm{R}=0.98$ & 47.349 & $2.51 \cdot 10^{-61}$ \\
\hline $5 \mathrm{~cm}$ & $\mathrm{Y}=0.8712 \cdot \mathrm{X}+3.3901$ & $\mathrm{R}=0.97$ & 36.812 & $9.23 \cdot 10^{-53}$ \\
\hline $10 \mathrm{~cm}$ & $\mathrm{Y}=0.8521 \cdot \mathrm{X}+3.3257$ & $\mathrm{R}=0.96$ & 32.133 & $3.12 \cdot 10^{-48}$ \\
\hline $20 \mathrm{~cm}$ & $\mathrm{Y}=0.8175 \cdot \mathrm{X}+3.6387$ & $\mathrm{R}=0.96$ & 31.383 & $1.88 \cdot 10^{-47}$ \\
\hline
\end{tabular}

given that $\mathrm{Y}$ - soil temperature, $\mathrm{X}$ - air temperature 
the studied period, winter seasons were generally less snowy than in the sixties or eighties.

Subsequent studies on the variation of dates of the beginning and end of thermal winter and the winter period conducted in 1960-2015 did not show statistically significant changes (Czarnecka and Niedzgorska-Lencewicz, 2017). However, the authors found a slight tendency of shortening of thermal winter and the number of winter days (the actual number of days with a negative daily air temperature). Earlier studies conducted in the Zagożdżonka River catchment of the profile in Czarna also showed that according to the Paczosa classification, in the period 2003-2013 moderately cold winters with extremely low snow precipitation dominated in the research area (Hejduk and Hejduk, 2014). The 2014-2018 period had predominantly mild winters with extremely low snow precipitation. Snow cover appears later and lasts shorter. There has been virtually no thick cover $(>20 \mathrm{~cm})$ in recent years.

Analysis of the incidence of frost, cold, cool, warm, hot and very hot days at the station in Czarna in 2009-2015 indicated an increase in the incidence of very hot and cold days and a decrease in the incidence of hot and frost days, as well as a stable remaining at a similar level the incidence of cool and warm days. An increase in the frequency of very hot days and a decrease in the frequency of frost days are a response to an increase in average air temperature. Similar results were obtained by other authors. Cebulak and Limanówka (2007) by analysing only the days with extreme (minimum and maximum) air temperature from 19 selected stations evenly distributed throughout the country in the 1951-2005 period showed an increasing tendency of very hot days and a decreasing tendency of frost days in a large area of Poland. The authors pointed to a decrease in the number of frost days, especially after 1972, except for the 1985-1987 period. After 1987, for 16 years there were no frosts reaching $-30^{\circ} \mathrm{C}$. At the same time, days with a maximum temperature exceeding $35^{\circ} \mathrm{C}$ were noted, and according to Kossowska-Cezak (2010) this phenomenon intensifies after 1990. Koźmiński and Michalak (2011) analysing the data from April-September from 38 IMGW first order stations for the years 1986-2009 found a statistically significant positive trend in the number of hot days, without clear changes in the number of warm and very hot days. The number of cold days in northern and central Poland showed a highly significant negative trend, while in the south-eastern part it was only significant. The number of cool days, however, decreased significantly in the southern and western regions of Poland.

The increase in air temperature, and consequently warmer winters and earlier dates of recent frosts extend the vegetation period (earlier beginning and later end), what has been reported both globally and in Poland over the last few years by Peano et al. (2019), Linderholm (2006), Tomczyk and Szyga-Pluta (2016), Nieróbca et al. (2013), Bochenek and Marczewski (2013). As a consequence, this change has an impact not only on agrotechnical measures and the proper selection of cultivated plants, but also on the species of fauna and flora. In Poland, the forests are dominated by trees such as pine, beech, oak, spruce, birch and alder. An increase in air temperature causes a change in the range of some of these species (e.g. pine). New plant species - but also insects and fungal pathogens (polypore, honey fungus) - may appear in areas where they did not occur so far. As for the research catchment, which is mainly used for agriculture, and forests cover only $20 \%$ of area, the growing season duration has not been studied, however in the light of increasing air temperature, changes in this area can be expected.

Depending on the depth of soil and its coverage, soil temperature is connected to basic meteorological elements, such as: air temperature, solar radiation intensity and precipitation (Oni et al, 2017; Fang et al., 2019, Bryś, 2008; Wojtkowski and Skower, 2017, Szyga-Pluta, 2018). The average soil temperature at the Czarna station varies depending on the depth of the soil profile. The average temperature at the ground surface $(0 \mathrm{~cm})$ in the 2009-2015 period showed an upward trend. At other depths this tendency was not evident. When measuring at a depth of $20 \mathrm{~cm}$, a slight, decreasing trend in changes of average temperature as well as in average summer and winter temperatures was observed.

The monthly distribution of average soil temperature at individual depths of the soil profile coincided with the monthly distribution of average air temperature. In both cases, the highest average temperature was recorded in July and the lowest in February. On a monthly basis, the average soil temperature at all examined depths of the soil profile was positive. Similar 
results were presented by Wojtkowski and Skowera (2017), also pointing out the seasonal variation of the relationship between soil temperature and air temperature. By analysing data from the station in Ojców for the 1991-2006 period, the authors proved that the strongest relationship between air temperature and soil temperature occurs in spring and autumn. In other seasons it is much weaker. Szyga-Pluta (2018) came to similar conclusions when studying the temperature variation in the soil profile at the station in Jezior in 2002-2015. Plant cover and snow cover affect soil temperature throughout its profile. At the same time, rainfall weakens the relationship between soil temperature and air temperature. Dry soils have poor conductivity and low heat capacity, therefore they heat up faster and have a higher temperature than moist soils (Rojek and Usowicz, 2018).

\section{CONCLUSIONS}

The following conclusions are to be drawn from the results of the air and soil temperature analysis at the Czarna station in 2009-2015:

1. The average air temperature for the 2009-2015 period at the Czarna station was $8.6^{\circ} \mathrm{C}$, showing an upward trend both annually and seasonally.

2. The distribution of average air temperature in individual months indicated that the coldest months were January, February and December, respectively. Positive average air temperature values were recorded in November, March and April. The warmest months were July, August and June. The average temperature in May and September was similar.

3. During the studied period, there was a decreasing tendency in the number of frost days, in contrast to cold and very hot days. The number of hot days in 2009-2015 remained at a similar level. The number of frost days showed the largest standard deviation (14.41), while the number of hot days the smallest. The highest coefficients of variation were recorded for the number of very hot (69\%) and frost (48\%) days.

4. The average soil temperature showed an upward trend for the surface layer. The average soil temperature at all depth levels demonstrated the highest values of coefficients of variation in the winter period. The medium-term rate of change was positive only for the average temperature at a depth of $0 \mathrm{~cm}$ both annually and semi-annually.

5. The monthly distribution of average soil temperature at individual depths of the soil profile coincided with the monthly distribution of average air temperature. At all analysed depths of the soil profile, the average temperature decreased from August to February, while it increased from March to July.

6. The relationship between air temperature and the temperature of the top soil layers was noted. It was the strongest just above the ground (correlation coefficient $\mathrm{R}=0.98$ ). The deeper the soil profile level, the lower the correlation coefficient, although it still remained at $\mathrm{R}=0.90$. At a depth of $20 \mathrm{~cm}$, the impact of air temperature on soil temperature was still strong $(\mathrm{R}=0.96)$.

\section{REFERENCES}

Banasik, K. (1994). Model sedymentogramu wezbrania opadowego w małej zlewni rolniczej. Warszawa: Wydawnictwo SGGW.

Banasik, K., Hejduk, L. (2013). Flow Duration Curves for Two Small Catchments with Various Records in Lowland Part of Poland. Rocznik Ochrona Środowiska, 15, 287-300.

Banasik, K., Hejduk, L., Hejduk, A., Kaznowska, E., Banasik, J., Byczkowski, A. (2013). Long-term variability of runoff from a small catchment in the region of the Kozienice Forest. Sylwan, 157(8), 578-586.

Barman, D., Kundul, D.K., Soumen, Pal, Susanto, Pal, Chakraborty, A.K., Jha, A.K., Mazumdar, S.P., Saha, R., Bhattacharyya, B. (2017). Soil temperature prediction from air temperature for alluvial soils in lower IndoGangetic plain. International Agrophysics, 31, 9-22.

Biernacka, B. (2010). Półempiryczne równanie opisujące naturalne pole temperatury gruntu $\mathrm{w}$ rejonie Białegostoku. Budownictwo i Inżynieria Środowiska, Oficyna Wydawnicza Politechniki Białostockie, 1, 5-9.

Bochenek, W., Dedo, J., Marczewski, W. (2013). Zróżnicowanie długości i warunków termicznych okresu wegetacyjnego na obszarze Beskidów i Pogórzy w latach 2001-2011 na podstawie danych zgromadzonych w bazie GLDAS. Monitoring Środowiska Przyrodniczego, 14, 79-85.

Byczkowski, A., Banasik, A., Hejduk, L., Mandes, B. (2001). Wieloletnie tendencje zmian procesów opadu i odpływu w małych zlewniach nizinnych (na przykła- 
dzie rzeki Zagożdżonki). W: Dynamika obiegu wody w zlewniach rzecznych, red. J. Jaworski i J. Sekutnicki, PTG IMGW Warszawa, 43-52.

Bryś, K. (2008). Wieloletni wpływ pokrywy roślinnej na termikę gleby. Acta Agrophysca, 12(1), 39-53.

Cebulak, E., Limanówka D. (2007). Dni z ekstremalnymi temperaturami powietrza. W: Piotrowicz K., Twardosz R. (red.), Wahania klimatu w różnych skalach przestrzennych i czasowych. Instytut Geografii i Gospodarki Przestrzennej, UJ Kraków, 185-194.

Czarnecka, M. (2012). Częstość występowania i grubość pokrywy śnieżnej w Polsce. Acta Agrophysica, 19(3), 501-514.

Czarnecka, M., Nidzgorska-Lencewicz, J. (2017). Zmienność termicznej zimy w Polsce w latach 1960-2015. Acta Agrophysica, 24(2), 205-220.

Fang, X., Luo, S., Lyu, S.(2019). Observed soil temperature trends associated with climate change in the Tibetan Plateau, 1960-2014. Theoretical and Applied Climatology, $135,169-181$.

Hejduk, A. Hejduk, L. (2014). Thermal and snow conditions of winters and winter floods on example of Zagożdżonka River. Annals of Warsaw University of Life Sciences SGGW, Land Reclamation, 46(1), 3-15, DOI: 10.2478/ sggw-2014-0001

Hejduk, L., Banasik, K., Hejduk, A. (2010). Monitoring of water quantity and quality for small catchment. Hydrologia w inżynierii i gospodarce wodnej. Monografie Komitetu Inżynierii Środowiska Polskiej Akademii Nauk, 68, 401-409.

Hejduk, L., Hejduk, A, Banasik, K. (2015). Determination of Curve Number for snowmelt-runoff floods in a small catchment changes in flood risk and perception in catchments and cities. Proceedings of the International Association of Hydrological Sciences (IAHS), 370, $167-170$.

IMGW (2015). Monitoringu Klimatu Polski.

IMGW (2015). Biuletyn Państwowej Służby Hydrologiczno-Meteorologicznej.

Jóźwik K. (2019). Zmienność temperatury powietrza i gleby na stacji w Czarnej w latach 2009-2015, SGGW, praca dyplomowa.

Jungqvist G., Oni S.K., Teutschbein C., Futter M.N. (2014). Effect of climate change on soil temperature in

Swedish boreal forests. PLOS ONE 9(4): e93957. DOI:10.1371/ journal.pone. 009395

Kossowska-Cezak, D. (2010). Fale upałów i okresy upalne - metody ich wyróżniania i wyniki zastosowania. Prace Geograficzne, zeszyt 123, Instytut Geografii i Gospodarki Przestrzennej UJ, Kraków, 143-14.
Koźmiński, C., Michalska, B. (2011). Zmienność liczby dni zimnych, chłodnych, ciepłych, gorących i upalnych w Polsce w okresie kwiecień-wrzesień. Przegląd Geograficzny, 83, 1, 91-107.

Kruk, E., Malec, M., Klatka, S., Brodzińska-Cygan, A. (2018). Concept of soil temperature coefficient for determining spatial distributio $\mathrm{n}$ of soil temperature. Acta Sci. Pol., Formatio Circumiectus, 17(2), 95-103. DOI: http://dx.doi.org/10.15576/ASP.FC/2018.17.2.95

Linderholm, H. (2006). Growing season changes in the last century. Agricultural and Forest Meteorology 137, 1-14.

Lorenc, H. (red.).(2005). Atlas klimatu Polski, Warszawa: IMGW.

Lorenc, H. (2000). Termiczno-opadowa ocena klimatycznych sezonów roku w Polsce oraz ich tendencje czasowo-przestrzenne. Projekt badawczy 9, IMGW, raport syntetyczny.

Marosz, M., Wójcik, R., Biernacik, D., Jakusik, E., Pilarski, M., Owczarek, M., Miętus, M. (2011). Zmienność klimatu Polski od połowy XX wieku. Rezultaty projektu KLIMAT, Prace i Studia Geograficzne, 47, 51-66.

Michalska, B. (2009). Variability of air temperature in North western Poland. in Z. Szwejkowski (red.), Environmental aspects of climate change, UW-M, Olsztyn, 89-107.

Michalska, B. (2011). Tendencje zmian temperatury powietrza w Polsce. Prace i Studia Geograficzne 2011, 47, $67-75$.

Mularz, S., Wróbel, A. (2003). Badanie rozkładu temperatury powierzchni terenu z wykorzystaniem zobrazowań termowizyjnych. Archiwum Fotogrametrii, Kartografii Teledetekcji. Zarząd Główny Stowarzyszenia Geodetów Polskich, 441-450.

Nieróbca, A., Kozyra, J., Mizak, K., Wróblewska, E. (2013). Zmiana długości okresu wegetacyjnego w Polsce, Woda - Środowisko - Obszary Wiejskie, 81-94.

Oni, S., Mieres, F., Futter, M., Laudon, H. (2017). Soil temperature responses to climate change along a gradient of upland-riparian transect in boreal forest. Climatic Change, 143, 27-41

Peano, D., Materia, S., Collalti, A., Alessandri, A., Anav, A., Bombelli, A., Gualdi, S. (2019). Global variability of simulated and observed vegetation growing season. Journal of Geophysical Research: Biogeosciences, 124. https://doi.org/10.1029/2018JG004881

Pralińska, M., Praliński, J. (2003). Badania statystyczne z Excelem. Warszawa: Wydawnictwo SGGW.

Rojek, E., Usowicz, B. (2018). Zmienność przestrzenna temperatury gleby w Polsce. Acta Agrophisica, 25 (3), 289-305. 
Szyga-Pluta, K. (2018). Roczna i dobowa zmienność temperatury gruntu na polanie śródleśnej w Wielkopolskim Parku Narodowym. Prace Geograficzne, 155, 69-83.

Tomczyk, A., Szyga-Pluta, K. (2016). Okres wegetacyjny w Polsce w latach 1971-2010. Przegląd Geograficzny, $88,1,75-86$.

Trepińska J. (2001). Fluktuacje termiczne w Europie od małej epoki lodowej do końca XX wieku. Prace i Studia Geograficzne, 29, 73-76.
Wojkowski, J., Skowera, B. (2017). Związek temperatury gleby z temperaturą powietrza w warunkach Jurajskiej Doliny Rzecznej. Inżynieria Ekologiczna, 18, 1, 18-26.

WMO. (2018). Statement on the State of the Global Climate in 2018. https://library.wmo.int/doc_num.php?explnum_id $=5789$.

Żmudzka, E. (2010). Changes in thermal conditions in the high mountain areas and con-temporary warming in the central Europe. Miscellanea Geographica, 14, 59-70.

\section{RELACJE POMIĘDZY TEMPERATURĄ POWIETRZA I GLEBY JAKO LOKALNY WSKAŹNIK ZMIAN KLI- MATU W MAŁEJ ZLEWNI ROLNICZEJ}

\section{ABSTRAKT}

\section{Cel pracy}

Celem pracy było rozpoznanie trendów zmian temperatury powietrza i temperatury gleby oraz ich wzajemnych zależności, jak również sprawdzenie, czy krótkie ciągi danych pomiarowych mogą być wskaźnikiem lokalnych zmian klimatu.

\section{Materiały i metody}

Podstawę obliczeń stanowiły dane pomiarowe temperatury powietrza oraz gleby na czterech głębokościach profilu glebowego, gromadzone $\mathrm{z}$ dziesięciominutowym krokiem czasowym na stacji w Czarnej w latach 2009-2015. Na podstawie posiadanych danych obliczono minimalną, maksymalną i średnią dobową temperaturę powietrza oraz gruntu na poszczególnych głębokościach profilu glebowego w ujęciu dobowym, miesięcznym, półrocznym i rocznym. Wartości średnie miesięczne posłużyły do wyznaczenia zależności pomiędzy temperaturą powietrza i gleby na poszczególnych głębokościach. W oparciu o temperaturę maksymalną powietrza obliczono liczbę dni mroźnych, zimnych, chłodnych, ciepłych, gorących i upalnych, zgodnie z metodyką podaną w Atlasie Klimatu Polski. Wyznaczono trendy zmian temperatury i regresję liniową. Zarówno w przypadku trendów jak i równań regresji liniowej sprawdzono istotność statystyczną współczynników równań przy zastosowaniu testu t-Studenta. Wyznaczono też podstawowe miary statystyczne.

\section{Wyniki i wnioski}

Wykazano istnienie statystycznie istotnego trendu rosnącego średniej temperatury powietrza w półroczu letnim. Średnia temperatura powietrza w zimie oraz w ujęciu rocznym również wykazuje tendencję wzrostową, lecz trend nie jest istotny statystycznie. Liczba dni mroźnych wykazuje tendencję malejąca, w przeciwieństwie do liczby dni zimnych i upalnych. Liczba dni gorących w badanym okresie pozostawała na podobnym poziomie. Średnia temperatura gleby wykazuje tendencję wzrostową dla w warstwy powierzchniowej, natomiast w warstwach głębszych zmienność temperatury jest bardziej zróżnicowana. Miesięczny rozkład średniej temperatury gleby jest zbieżny z miesięcznym rozkładem średniej temperatury powietrza. Wykazano związek pomiędzy temperaturą powietrza, a temperaturą wierzchnich warstw gleby.

Słowa kluczowe: mała zlewnia rolnicza, temperatura powietrza, temperatura gleby, tendencje zmian temperatury powietrza i gleby 